\title{
ANALYSIS OF FARMERS' ADOPTION OF CLIMATE SMART AGRICULTURAL PRACTICES IN NORTHERN NIGERIA
}

\author{
Saliu Akinlabi Tiamiyu ${ }^{1 *}$, Uduma Bernadette Ugalahi ${ }^{1}$, Timothy Fabunmi ${ }^{2}$, \\ Rahman O. Sanusi ${ }^{2}$, Enitan Oluwakemi Fapojuwo ${ }^{2}$ and Adebayo Musediku Shittu ${ }^{2}$ \\ ${ }^{I}$ National Cereals Research Institute, Badeggi, PMB 8, Bida, Niger State, Nigeria \\ ${ }^{2}$ Federal University of Agriculture, Abeokuta, PMB 2240, Abeokuta, Ogun State, Nigeria \\ E-mail:*satiamiyu2@gmail.com
}

\begin{abstract}
Climate change is becoming a threat to sustainable agricultural production and food security in Africa. Farmers need to be more resilient to climate change and produce more food through adoption of Climate Smart Agricultural Practices. The objective of this study was to determine the extent of farmers' adoption of selected Climate Smart Agricultural practices in the North Western geopolitical zone of Nigeria. A multistage sampling procedure was used to select sample of 577 farmers who cultivate rice and maize as major crops across three distinct vegetation strata. Data were collected through interview schedule with the aid of questionnaire. Data were analyzed using descriptive statistics. The results showed that adoption of the selected agricultural practices was generally low. Agronomic components were the mostly adopted practice. Practices such as Integrated Pest/Weed Management, agro-forestry, efficient soil fertilization and water management were not highly adopted. Bush burning remained a major setback towards effort of building resilience to climate change in the study area. Sensitization of farmers on reality of climate change and the need to adopt climate smart practices towards reduction of adverse effect of climate change should continue. Policy and support programme that would enhance dissemination of Climate-Smart Agricultural practices to a larger proportion of farmers is recommended.

Keywords: Climate Change, Climate Smart Practices, Adoption, Nigeria
\end{abstract}

\section{Introduction}

Agricultural activities relied greatly on climate. It determines the pattern of vegetation, types and yields of crops and animals as well as the length of cropping seasons. It follows therefore that any change in climate may affect the production and supply of food and raw materials thereby enhancing or limiting the capacity of agriculture to play its major role as supplier of food and industrial raw materials. Climate change has been fairly rapid in many regions around the world in the last few decades, while greenhouse gas emission keeps on increasing. The uncertainty as to how the trend of climate change and greenhouse gas emission will continue in the future raises many questions related to food security, one of which is whether the aggregate productivity of global agriculture will be affected. According to FAO, 2014 climate change is likely to cause considerable crop yield losses thereby adversely affecting small holder livelihoods in Africa. As a result, food security and income generation opportunities for the farming households that are most reliant on agriculture may be in jeopardy (FAO, 2014). It is projected that crop yield in Africa may fall by $10-20 \%$ by 2050 or even up to $50 \%$ due to climate change (Jones, 2003, Nwaobiala and Nottidge, 2013). This is because African agriculture is predominantly rain-fed and hence fundamentally dependent on the vagaries of weather (Zoellick, 2009). It is therefore, important that measures are taken to mitigate the consequences of climate changes. The recent adoption of the Paris Agreement demonstrates the global acknowledgement of the negative impacts of climate change to human populations and the environment. The challenges of how to turn the promises of that historic Paris climate change agreement into reality necessitates the need for an agricultural practices that would help farmers produce more, be more 
resilient to climate change and reduce greenhouse gas emissions from livestock, crops, and land use change. Climate Smart Agriculture was developed to address those important needs.

Climate-Smart Agricultural (CSA) practices ensure food sufficiency despite unsuitable climatic conditions. This is achieved through several soil management practices that sequester carbon in the soil, reduce greenhouse gas emissions and aids intensify production (FAO, 2013). Above all the practices enhance the natural resource base. The most important premise of CSA is the building of healthy soils through increasing the soil organic matter status of the soil. Soil management practices for CSA include; direct seeding under reduced-tillage (Zheng et al., 2014); improved protective soil cover through cover crops, crop residues or mulch (Muzangwa et al., 2013); and crop diversification through rotations (Lin, 2011; Davis et al., 2012). Integrated soil fertility management, which involves combining inputs of organic matter i.e. mulch, compost, crop residues and green manure with fertilizers to prevent macro- and micro-nutrient deficiencies is a good CSA practice as well (FAO, 2013).

Several studies on climate and agriculture have been carried out in Nigeria. Some of them focused on the effect of climatic variables on agricultural production (Ogbuene, 2010, Olanrewaju, 2010, Ogundelele and Jegede, 2011, Akpenpuun and Busari 2013, Nwaobiala and Nottidge 2013, Oluyole, et al, 2013, Tiamiyu, et al, 2015) while some reported farmers' perception of climate change and adaptation strategies (Ayanlade, et al 2017). From these studies it is obvious that climate change is real and has significantly impacted on agricultural production in Nigeria. Although studies have shown that various adaptation strategies were adopted by farmers against the effect of climate change, little is specifically known about farmers' adoption of Climate Smart Agricultural practices in Nigeria. The objective of this study therefore, is to analyse the extent of adoption of CSA among cereals farmers in North Western Nigeria. The study is expected to provide baseline information which can be used in formulating new policy and supportive programmes towards adoption of Climate Smart Agricultural Practices by cereals farmers in Nigeria.

\section{Methodology}

The study was conducted in four states located in the North Western geo-political zone of Nigeria. The study area lies between Latitude $5.064^{\circ}$ to $13.087^{\circ}$ East and Longitude $3.662^{\circ}$ to $13.087^{\circ}$ North. Major vegetation strata of the area are guinea savannah, Sudan savannah and Sahel savannah which are suitable for production of various kinds of crops especially maize and rice. Primary data was collected through interview schedule with structured questionnaires. The interview was conducted by the researchers in conjunction with trained enumerators chosen from among the staff of Agricultural Development Programmes (ADPs) of the selected states. Multistage sampling technique was used to select respondent farmers that provided information for this study. The first stage involved purposive selection of one zone (North West) from the list of six geo-political zones in Nigeria. The second stage involves selection of four states (Kaduna, Kano, Kebbi, Sokoto) from the list of states in the selected zone based on predominant vegetation strata. The third stage of sampling was the selection of villages from each Agricultural Development zones of the selected states. In the fourth stage, 10 to 15 farmers were randomly selected from each selected villages on the basis of probability proportionate to size. A total of 577 respondents across three vegetation strata provided information for the study. The distribution of sample respondents is as presented in Table 1.

The following Climate Smart Agricultural Practices (Branca, 2011, FAO, 2013, Saguye, 2017) were examined:

i. Agronomic practices (Improved seed varieties, crop rotation, intercropping, cover crop);

ii. Integrated Soil Fertility Management (Organic fertilizer, efficient use of inorganic fertilizer);

iii. Tillage and residue Management (Conservation tillage, incorporation of crop residues); 
iv. Water Management (Irrigation, bunds, terracing, Contouring, water harvesting);

v. Integrated Pest Management (blend of cultural, biological and chemical control);

vi. Agro-forestry (Intercropping crops and trees, Live fencing).

Data were analyzed using descriptive statistics including arithmetic mean and percentage. Adoption rate was based on the percentage of adopters in the total sample (Saguye, 2017). The following criteria were used to rank the rate of adoption:

Adoption rate greater than $70 \%=$ very high,

Adoption rate within 60 to $70 \%=$ high,

Adoption rate within 50 to $59 \%$ = fairly high,

Adoption rate within 40 to $49 \%$ = fairly low

Adoption rate below $40 \%=$ very low.

Table 1: Distribution of respondent sample according to location

\begin{tabular}{lllll}
\hline Location & Guinea savannah & Sudan Savannah & Sahel Savannah & Total \\
\hline Kaduna & 149 & 1 & 2 & 152 \\
\hline Kano & 1 & 104 & 36 & 141 \\
\hline Kebbi & 2 & 61 & 91 & 154 \\
\hline Sokoto & 6 & 0 & 124 & 130 \\
\hline Total & 158 & 166 & 253 & 577 \\
\hline
\end{tabular}

Source: Field Survey, 2017

\section{Results and Discussion}

Generally farmers' adoption rates of the agricultural practices examined in this study were very low. This finding corroborates with a recent study which similarly indicated low adoption of climate smart agriculture in Ethiopia (Saguye, 2017). Practices such as planting of early maturing, drought tolerant and use of farm yard manure/compost were highly adopted. Cultivation of disease/pest resistant varieties and intercropping cover crops with main crop(s) to improve soil fertility were also fairly adopted while adoption of other components of climate smart practices was low. Distribution of respondents according to the level of awareness and adoption of the selected practices were presented in Tables 2 to 7.

Table 2 presents the rates of awareness and adoption of agronomic practices. Cultivation of early maturing and drought tolerant varieties was the most highly adopted practice. Cultivation of disease/pest resistant varieties and intercropping cover crops with main crops as a way of improving soil fertility was also highly adopted. Growing appropriate mix of crops in rotation on same parcel was fairly adopted. The high adoption of early maturing and drought tolerant varieties is expected in view of short rainfall duration in the zone. Another reason for high adoption of improved seed varieties is the favourable policy environment for development and distribution of improved seed varieties to farmers. There is a specialized body- National Seed Certification Council of Nigeria - which was established specifically to administered seed release and production in the country. Research and extension activities were also widely focused on breeding of improved varieties which has led to the release of some rice varieties to farmers (NCRI, 2014). 
Table 2: Level of awareness and adoption of Climate Smart Agronomic practices

\begin{tabular}{llll}
\hline Agronomic practices & Not aware (\%) & $\begin{array}{l}\text { Aware but never } \\
\text { adopted (\%) }\end{array}$ & $\begin{array}{l}\text { Adopted } \\
(\%)\end{array}$ \\
\hline $\begin{array}{l}\text { Cultivation of early maturing and drought } \\
\text { tolerant varieties }\end{array}$ & 13 & 24 & 63 \\
\hline Cultivation of disease/pest resistant varieties & 20 & 25 & 55 \\
\hline $\begin{array}{l}\text { Intercropping cover crops with main crop(s) } \\
\text { to improve soil fertility }\end{array}$ & 20 & 24 & 56 \\
\hline $\begin{array}{l}\text { Growing appropriate mix of crops in rotation } \\
\text { on same parcel }\end{array}$ & 17 & 34 & 49 \\
\hline
\end{tabular}

\section{Fertilization}

Fertilizer use enhances the capacity of improved seed varieties to express yield potential optimally. To be climate smart however, the blend of both organic manure and inorganic fertilizer is recommended (FAO, 2013). The level of awareness and adoption of fertilization is presented in Table 3. Farm yard manure was the most adopted among the fertilization components. This could be attributed to mixed farming practices which make farm yard manure relatively cheaper than other source of manure in the study area. However, farmers apply the farm yard manure based on availability, there was no standard rate. The adoption of green manure and inorganic fertilizer micro-dosing was very low. The low adoption of green manure is attributed to scarcity and lack of knowledge on composite preparation and low awareness of the agro-forestry practices that would have enable them to generate green manure cheaply on farmers' fields. Awareness of fertilizer micro-dosing was also low. The reason was attributed to lack of training facilities and lack of access to soil testing equipments.

Table 3: Level of awareness and adoption of Climate Smart Fertilization practices

\begin{tabular}{llll}
\hline Fertilization practices & Not aware (\%) & $\begin{array}{l}\text { Aware but never } \\
\text { adopted (\%) }\end{array}$ & Adopted (\%) \\
\hline $\begin{array}{l}\text { Deliberate cultivation and ploughing in of } \\
\text { certain leguminous plants into the soil as } \\
\text { green manure }\end{array}$ & 44 & 22 & 34 \\
\hline $\begin{array}{l}\text { Preparation and use of Farm Yard Manure } \\
\text { and/or Compost }\end{array}$ & 17 & 22 & 36 \\
\hline $\begin{array}{l}\text { Efficient application of fertilizers in split - } \\
\text { small but repeated -dosages based on } \\
\text { assessments of crop needs - micro-dosing }\end{array}$ & 42 & 22 & \\
\hline
\end{tabular}

\section{Tillage and residue management}

Level of awareness and adoption of Tillage and Residue Management practices is presented in Table 4. Generally the adoption rates of the practices was low. Awareness of incorporating plant residue into the soil instead of burning during land preparation was very low. The practice of bush burning is common because of the general believe that it provide cheap source of potash fertilizer. However, farmers lack the knowledge of the danger pose by the practice to the environment. Low adoption of minimum tillage could be attributed to the availability of tractor hiring services which makes cultivation of large expanse of land easy. 
Table 4: Level of awareness and adoption of Climate Smart Tillage and Residue Management practices

\begin{tabular}{llll}
\hline & Not aware (\%) & $\begin{array}{l}\text { Aware but never } \\
\text { adopted (\%) }\end{array}$ & Adopted (\%) \\
\hline $\begin{array}{l}\text { Retention / incorporation of refuse into the } \\
\text { soil rather than burning }\end{array}$ & 22 & 29 & 49 \\
\hline $\begin{array}{l}\text { Minimizing tillage operation to conserve soil } \\
\text { moisture and health }\end{array}$ & 33 & 34 & 33 \\
\hline
\end{tabular}

\section{Water management}

Level of awareness and adoption of Water Management practices is presented in Table 5. Considering the short rainfall duration of the Sudan and Sahel savannah which constitute more than half of the total land area of the North Western zone of Nigeria, it is highly expected that large proportion of farmers in the study area should adopt water management practices. The result showed a very low aadoption of the practice. The reason could be traced to low level of technical knowledge.

Table 5: Level of awareness and adoption of Climate Smart Water Management practices

\begin{tabular}{llll}
\hline & Not aware (\%) & $\begin{array}{l}\text { Aware but never } \\
\text { adopted (\%) }\end{array}$ & Adopted (\%) \\
\hline $\begin{array}{l}\text { Construction of terraces on sloppy / hilly } \\
\text { farmland }\end{array}$ & 35 & 26 & 39 \\
\hline $\begin{array}{l}\text { Use of Drip or Sprinkler Irrigation in } \\
\text { upland/dryland conditions }\end{array}$ & 51 & 25 & 24 \\
\hline $\begin{array}{l}\text { Use of controlled flooding before \& during } \\
\text { cultivation - i.e. alternate wet and dry systems } \\
\text { - in flooded rice / lowland production systems }\end{array}$ & 48 & 22 & 30 \\
\hline $\begin{array}{l}\text { Water harvesting and conservation by } \\
\text { construction of bounds }\end{array}$ & 42 & 28 & 30 \\
\hline Mulching to conserve soil water & 34 & 28 & 38 \\
\hline
\end{tabular}

\section{Integrated Pest Management}

As presented in Table 6, the adoption rate of IPM was very low despite a fairly high awareness of the practice. Although several training and lecture on IPM have been delivered by experts, the dissemination of the practice to the end user especially biological and cultural methods by extension workers was rarely demonstrated.

Table 6: Level of awareness and adoption of Climate Smart Pest Management practices

\begin{tabular}{llll}
\hline & Not aware (\%) & $\begin{array}{l}\text { Aware but never } \\
\text { adopted (\%) }\end{array}$ & Adopted (\%) \\
\hline Integrated pest and/or weed management & 49 & 22 & 29 \\
\hline
\end{tabular}

\section{Agro-forestry}

The study area is mainly Sudan and Sahel savannah which are prone to desertification. The dissemination of this practice to farmers is expected to be intensive in the study area. Contrary to expectation, the rate of adoption of Agro-forestry is very low as presented in Table 7. Farmers in this area have exposure to tree planting; however they prefer planting those ones that generate economic benefit in the short run. Trees like mango, oranges, neem, shea and locust bean are commonly preserved by farmers in the study area for economic reason. Training on agro-forestry practices should be extended to the famers in the study area. 
Table7: Level of awareness and adoption of Climate Smart Agro-forestry Practice

\begin{tabular}{llll}
\hline Agro-forestry practice & Not aware (\%) & $\begin{array}{l}\text { Aware but never } \\
\text { adopted (\%) }\end{array}$ & $\begin{array}{l}\text { Adoption rate } \\
(\%)\end{array}$ \\
\hline $\begin{array}{l}\text { Integration cultivation of appropriate tree } \\
\text { species along with crops on farm land either } \\
\text { by block planting, alley cropping, etc. - } \\
\text { agroforestry }\end{array}$ & 46 & 29 & 25 \\
\hline
\end{tabular}

\section{Conclusion}

The study examined the extent of farmers' adoption of climate smart agricultural practices as baseline for intervention on climate mitigation measures. The results indicate that a large proportion of respondents was not aware of most of the practices and so, adoption of most of the practices examined were very low. Agronomic practices in term of cultivation of high yielding, drought tolerant, disease and pest resistant seed varieties was the most adopted practice due to long time of research and extension activities on seed varieties as well as favourable government policy and support prograrmme on seed production and utilization in the country. Adoption of Integrated Pest Management, water management, integrated soil fertility management and agroforestry were very low. Burning of plant residues is a practice that farmers found very difficult to stop. This raise the question as to when the age long practice of bush burning will end especially when considering the risk posed by bush burning to climate change mitigation measure. Effort should be made to encourage farmers in the study area to adopt climate smart agricultural practices as a whole by following the recommendations as listed:

- Sensitization campaign on reality of climate change and the need to adopt climate smart practices towards reduction of adverse effect of climate change should be intensified.

- Policy and supportive programmes towards climate change mitigation and adaptation in the study area should focus on adoption of all Climate Smart Agricultural practices especially those ones that were not highly adopted by farmers.

- Efforts should be made by research institution to train extension staff properly about all the components of climate smart agricultural practices.

- Extension staff should in turn disseminate extensively accurate information on Climate-Smart Agricultural practices to cover a larger proportion of farmers in the study area.

- Government should provide incentives and enabling policy environment towards adoption of good CSA practices in general and specifically those ones that were not highly adopted.

- Tree planting campaign should be modified in such a way that economic trees would be accommodated.

- Credit facilities should be provided in order to enhance the capacity of farmers in procuring the necessary climate smart inputs

\section{Acknowledgement}

This study was carried out by Federal University of Agriculture (FUNAAB), Abeokuta in collaboration with the National Cereals Research Institute (NCRI), Badeggi, as part of the ECOWAS-RAAF-PASANAO project 0824/2016: 'Incentivizing Adoption of Climate Smart Agricultural Practices in Cereals Production in Nigeria: The Socio-cultural and Economic Diagnosis' which was funded by the Regional Agency for Agriculture and Food (RAAF) of the Economic Community of West African States (ECOWAS) under the Support Programme 
for Food and Nutrition Security in West Africa (PASANAO). We appreciate the efforts of all the project participants from FUNAAB, NCRI and the Agricultural Development Programmes of Kaduna, Kano, Kebbi and Sokoto states towards the successful data collection in the North Western zone of Nigeria.

\section{References}

Akpenpuun, T.D. and Busari R.A., 2013, Impact of Climate on Tuber Crops Yield in Kwara State, Nigeria, American International Journal of Contemporary Research, 3(1), 179-183

Apata, T.G., 2011, Effects of Global Climate Change on Nigerian Agriculture: An Empirical Analysis, CBN Journal of Applied Statistics, 2(1), 31-50

Ayanlade, A., M., Radeny and Morton, J. F., 2017, Comparing smallholder farmers' perception of climate change with meteorological data: A case study from southwestern Nigeria, Weather and Climate Extremes, 15, 24-33

Branca, G, McCarthy, N, Lipper L, Jolejole M.C. 2011, Climate smart agriculture: a synthesis of empirical evidence of food security and mitigation benefits from improved cropland management. Mitigation of Climate Change in Agriculture (MICCA) series 3, Rome, Food and Agriculture Organization of the United Nations.

FAO 2013, Climate-Smart Agriculture Sourcebook. Food and Agriculture Organization of the United Nations, Rome. http://www.fao.org/docrep/018/i3325e/i3325e04.pdf 22/12/16

FAO, 2014, Adoption of Climate-Smart Agricultural Practices: Barriers, Incentives, Benefits and Lessons Learnt from the MICCA Pilot Site in Kenya. Final Report prepared by Morgan C. Mutoko for MICCA Programme in December, 2014

IPCC, 2007, The Science Basic. Third Assessment Report. Inter-governmental Panel on Climate Change, Cambridge University Press, Pp.335.

Jones, J. W. 2003, Agricultural Responses to Climate Variability and Change. Paper Presented at the Climate Change Net Conference. "Insights and Tools for Adaptation Learning from Climate Variability", November 1920, Washington D.C, USA.

Lin, B. B., 2011, Resilience in Agriculture through crop diversification: Adaptive management for environmental change, BioScience 61,183 - 193

Muzangwa, L., Chiduza, C. and Muchaonyerwa, P. 2013, Feasibility of Winter Cover Crop Production under Rainfed Conditions in the Eastern Cape Province of South Africa, African Crop Science Journal, 21, 73-184.

Nciizah, A.D. and Wakindiki I.I.C., 2015, Climate Smart Agriculture: Achievements and Prospects in Africa, Journal of Geoscience and Environment Protection, 3, 99-105

NCRI, 2014, Best practices and Natural Resources Management for rice production in Nigeria, National Cereals Research Institute, pp54

Nwaobiala, C. U. and Nottidge, D. O 2013, Effect of Climatic variables on cassava production in Abia State, Nigeria, Nigerian Journal of Agriculture, Food and Environment, 9(4), 57-62

Ogbuene, E.B. ,2010, Impact of meterological parameters on rice yield: An approach for environmental resource sustainability in Ebonyi rice farmland, Nigeria, Journal of Environmental Issues and Agriculture in Developing Countries, 2,103-116

Ogundele, J.A. and Jegede, A., 2011, Environmental impact of climate change on agricultural production in Ekiti State, Nigeria, Journal of Environmental Issues and Agriculture in Developing Countries, 3,72-79

Olanrewaju, R.M. 2010, Climate and rice production in a part of the Niger River Basin Development Authority, A case study of Edu and Lafiagi LGA of Kwara State, Nigeria, Journal of Meteorology and Climate Science, $8(2), 102-110$

Oluyole, K.A., Emaku, L.A., Aigbekan, E.O. and Oduwole, O.O., 2013, Overview of the trend of climate change and its effect on Cocoa production in Nigeria, World Journal of Agricultural Research 1(1): 10-13

Saguye, T. S., 2017, Assessment of Farmers' Perception of Climate Change and Variability and its Implication for Implementation of Climate-Smart Agricultural Practices; the case of Geze Gofa District, Southern Ethiopia, Journal of Geography \& Natural Disasters, 7(191):1-9

Tiamiyu, S.A., Eze, J. N., Yusuf, T. M., Maji, A.T. and Bakare, S. O., 2015, Rainfall Variability and Its Effect on Yield of Rice in Nigeria, International Letters of Natural Sciences, 49:63-68 
World Bank, 2012, The Climate Finance Options "platform hosted by the World Bank and United Nations Development Programme. Climate Finance Tracking window. Available from: http://www.climatefinanceoptions.org/cfo/ 22/12/16.

World Bank (2014) Foster Climate-Smart Agriculture. http: //www.worldbank.org /en/topic/agriculture/brief/foster-climate-smart-agriculture 22/12/16

Zheng, C., Jiang, Y., Chen, C., Sun, Y., Feng, J., Deng, A., Song, Z., et al. (2014). The Impacts of Conservation Agriculture on Crop Yield in China Depend on Specific Practices, Crops and Cropping Regions. The Crop Journal, 2, 289-296. http://dx.doi.org/10.1016/j.cj. 22/12/16

Zoellick, R. B. 2009. A Climate Smart Future. The Nation Newspapers, April 16 